\title{
Mempertahankan Eksistensi Desa Wisata dengan Kearifan Lokal (Studi kasus : Tracking Terbit Menoreh di Dusun Madigondo, Samigaluh, Kulon Progo)
}

\author{
Tutun Seliari \\ Prodi Arsitektur, Fakultas Arsitektur dan Desain, Universitas Kristen Duta Wacana \\ Jl. Dr. Wahidin Sudirohusodo 5-25, Yogyakarta \\ tutunseliari@staff.ukdw.ac.id
}

\begin{abstract}
Abstrak
Pada masa Covid-19 di Indonesia sektor yang mengalami dampak sangat besar yaitu sektor pariwisata, begitu juga yang dialami oleh Dusun Madigondo. Dusun Madigondo terletak di Desa Sidoharjo, Kecamatan Samigaluh, Kabupaten Kulon Progo, Daerah Istimewa Yogyakarta, berada pada kawasan program Jalur Bedah Menoreh yang dikembangkan Pemerintah Daerah Istimewa Yogyakarta. Saat ini di Dusun Madigondo dikembangkan Wisata Tracking Terbit Menoreh (TTM) yang mengintegrasikan spot-spot potensi di Dusun Madigondo, antara lain pemandangan alam, kebun kopi, sejarah dan religi, kearifan lokal, kuliner, dan industri kreatifnya. Saat masa pandemic Covid-19, eksistensi Dusun Madigondo dimana sektor pariwisata menjadi andalan untuk peningkatan kegiatan ekonomi masyarakat menjadi terancam. Perlu strategi yang baik agar kondisi pariwisata di Dusun Madigondo ini tetap bertahan. Dusun Madigondo dengan atraksi Tracking Terbit Menoreh dipilih sebagai suatu wilayah yang menawarkan sumber daya alam dan budaya, di mana kearifan lokal masih aktif digunakan, tetapi jarang dianggap sebagai aset yang dapat dinilai untuk bertahan dari bencana dan pengembangan masa depan. Tujuan penelitian ini mengeksplorasi kearifan lokal masyarakat sehingga dapat mempertahankan eksistensinya pada masa pandemi Covid-19. Tulisan ini juga mendokumentasikan inisiatif dan praktek lokal dalam kehidupan masyarakat di Dusun Madigondo pada saat masa pandemi Covid-19. Metode yang digunakan adalah penelitian tindakan (action research), melalui pemetaan swadaya, focus group discussion (FGD) dan participatory design (workshop). Hasil penelitian ini adalah kearifan lokal di masyarakat Dusun Madigondo berupa tanaman rempah empon-empon dan pengetahuan masyarakat dalam mengolahnya, menjadi bagian dari tatanan lanskap dan identitas wisata Tracking Terbit Menoreh. Partisipasi komunitas dan masyarakat Dusun Madigondo dalam mengidentifikasi permasalahan dan merumuskan solusi bersama menjadi aspek yang sangat penting dalam mempertahankan eksistensinya sebagai desa wisata yang berbasis ekowisata. Selain menjadi bagian dari lanskap atraksi wisata tanaman herbal empon-empon ini juga sebagai bagian dari pengembangan industri kreatif di Dusun Madigondo sehingga dapat meningkatkan perekonomian masyarakat.
\end{abstract}

Kata kunci : Wisata Tracking, Ekowisata, Tanaman Empon-Empon, Kearifan Lokal, Eksistensi Destinasi

\section{Maintaining The Existence of a Tourist Village With Local Wisdom (Case Study : Tracking Terbit Menoreh in Madigondo Hamlet, Samigaluh, Kulon Progo)}

\section{Abstract}

During the Covid-19 period in Indonesia, the sector that experienced a very large impact was the tourism sector, as was experienced by Madigondo Hamlet. Madigondo Hamlet is located in Sidoharjo Village, Samigaluh District, Kulon Progo Regency, Special Region of Yogyakarta, located in the "Jalur Bedah Menoreh" program area developed by the Yogyakarta Special Region Government. Currently, in Madigondo Hamlet, the Tracking Terbit Menoreh (TTM) attraction is being developed which integrates potential spots in Madigondo Hamlet, including natural scenery, coffee plantations, history and religion, local wisdom, culinary, and creative industries. During the Covid-19 pandemic, the existence of Madigondo Hamlet where the tourism sector was the mainstay for increasing community economic activities was threatened. A good strategy is needed so that the tourism condition in Madigondo Hamlet can survive. Madigondo Hamlet with the Tracking Terbit Menoreh (TTM) attraction was chosen as an area that offers natural and cultural resources, where local wisdom is still actively 
used but is rarely considered an asset that can be valued to survive disasters and future development. The purpose of this study is to explore the local wisdom of the community so that it can maintain its existence during the Covid-19 pandemic. This paper also documents local initiatives and practices in people's lives in Madigondo Hamlet during the Covid-19 pandemic. The method used is action research, through self-help mapping, focus group discussions (FGD), and participatory design (workshops). The results of this study are local wisdom in the Madigondo Hamlet community in the form of 'empon-empon' spice plants and community knowledge in processing them, becoming part of the landscape arrangement and tourist identity of Tracking Terbit Menoreh. Community and community participation in Madigondo Hamlet in identifying problems and formulating solutions is a very important aspect in maintaining its existence as an ecotourism-based tourism village. In addition to being part of the tourist attraction landscape, these 'empon-empon' herbal plants are also part of the development of the creative industry in Madigondo Hamlet so that it can improve the community's economy.

Keyword: Tracking Tourism, Ecotourism, 'Empon-Empon' Plants, Local Wisdom, The Existence of Destinations

\section{PENDAHULUAN}

Dusun Madigondo terletak di Desa Sidoharjo, Kecamatan Samigaluh, Kabupaten Kulon Progo, Daerah Istimewa Yogyakarta, berada pada kawasan program Jalur Bedah Menoreh yang dikembangkan Pemerintah Daerah Istimewa Yogyakarta. Hal ini merupakan kesempatan bagi Dusun Madigondo untuk menangkap peluang sebagai destinasi wisata dalam rangka meningkatkan ekonomi masyarakat. Jalur Bedah Menoreh merupakan salah satu akses jalan yang menghubungkan kawasan wisata Borobudur dengan Bandara New Yogyakarta International Airport (NYIA). Hal tersebut bisa dijadikan peluang untuk meningkatkan ekonomi dan nilai kawasan di daerah sekitar. Kawasan Pegunungan Menoreh banyak terdapat tanaman kopi dari jenis arabika maupun robusta. Tanaman kopi dikembangan dan ditanam dengan sistem tumpang sari berada di antara tanaman kebun yang lainnya seperti misalnya tanaman moka sehingga kopi yang dihasilkan menjadi ciri khas tersendiri dibandingkan dengan kopi di daerah lain. Dusun Madigondo saat ini dikembangkan menjadi desa wisata ritisan yang mempunyai potensi utama penghasil kopi moka.

Potensi lain di Dusun Madigondo berupa topografi keindahan alam, kearifan lokal, budaya, religi, historis, kerajinan hingga kuliner dikembangkan menjadi suatu daya tarik wisata. Potensi-potensi tersebut dikemas dalam sebuah atraksi wisata yaitu yang di branding dengan nama Tracking Terbit Menoreh (TTM). Wisata TTM merupakan wisata tracking jalan kaki menyusuri spot-spot potensi di Dusun Madigondo. Dalam kegiatan Tracking ini, TTM tidak hanya mempunyai jalur di Dusun Madigondo tetapi juga melintasi Dusun Majaksingi, Desa Kapuhan, Kecamatan Borobudur, Jawa Tengah. Gambar 1 merupakan peta perjalanan Tracking TTM yang merupakan rangkaian dari potensi di Dusun Madigondo dan Dusun Majaksingi, antara lain potensi keindahan alam, wisata kopi, sejarah perjalanan Pangeran Diponegoro dan Nyi Ageng Serang, wisata air, Gua Maria, Sanggar Panepen Tirto Lanceng yang bisa digunakan oleh semua umat beragama, kerajinan dan kuliner.
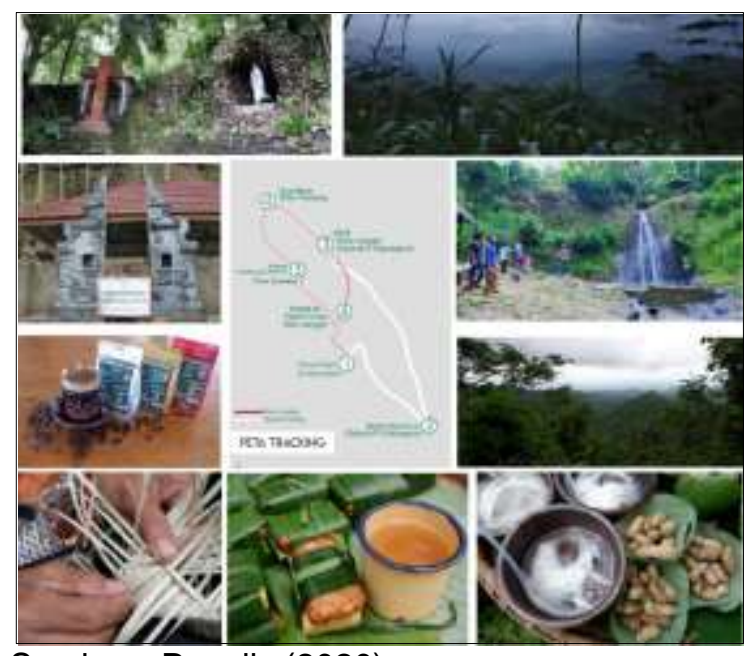

Sumber : Penulis (2020)

Gambar 1. Peta dan potensi Tracking Terbit Menoreh (TTM)

Pada masa pandemi Covid-19 ini sektor yang mengalami dampak besar di Indonesia adalah sektor pariwisata. Banyak destinasi wisata mengalami penurunan pengunjung yang berdampak terhadap eksistensi daerah tersebut menjadi sebuah destinasi wisata. 
Dampak penurunan pengunjung juga terjadi di Kabupaten Kulon Progo.

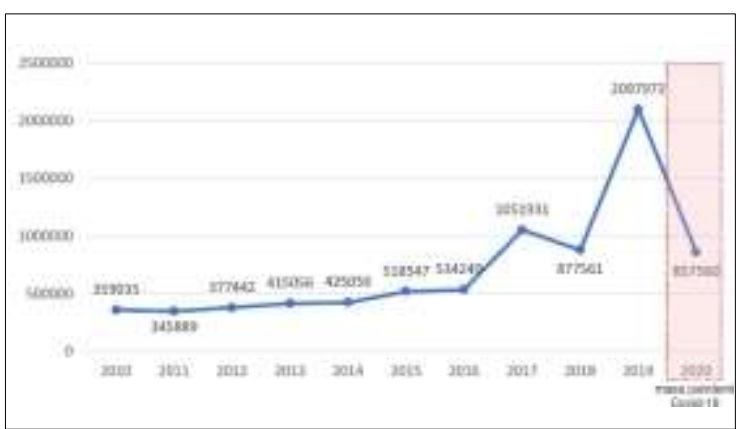

Sumber : Kulon Progo Dalam Angka Tahun Badan Pusat Statistik Kabupaten Kulon Progo (2011-2021)

Gambar 2. Grafik Jumlah Kunjungan Wisatawan di Kulon Progo

Berdasarkan Gambar 2 dapat kita lihat pada masa pandemi Tahun 2020 Kabupaten Kulon Progo mengalami penurunan wisatawan sebanyak 59,12\% dibandingkan tahun 2019 . Hal tersebut berdampak bagi Dusun Madigondo. Dusun Madigondo mengalami dampak terhadap kehidupan masyarakat dan aktivitasnya. Permasalahan yang diangkat dari penelitian ini adalah bagaimana keberadaan eksistensi Dusun Madigondo yang akan dikembangkan menjadi desa wisata bisa bertahan di masa pandemi Covid-19. Penelitian ini mempunyai fokus pada Dusun Madigondo, Samigaluh, Kulon Progo, terutama terhadap aktivitas Tracking yang menjadi atraksi wisata di Dusun Madigondo.

\section{KAJIAN PUSTAKA}

Penelitian ini mengangkat eksistensi Dusun Madigondo dengan kearifan lokalnya yaitu berupa tanaman rempah empon-empon. Rempah bermanfaat dalam bentuk rimpang dikenal sebagai kelompok empon-empon, meliputi antara lain kunyit, kencur, jahe, lengkuas, laos dan lainnya (Hakim, 2015: 21).

Perangkat pengetahuan dan praktek pada sebuah komunitas (baik yang berasal dari generasi sebelumnya atau dari pengalaman) untuk menyelesaikan sebuah persoalan dan/atau kesulitan merupakan sebuah kearifan lokal (Ahimsa, 2009: 39-40). Sumarmi dan Amirudin (2014) dalam Prabandari (2018: 274-275) menjelaskan bahwa kearifan lokal merupakan pengetahuan lokal yang digunakan oleh masyarakat untuk bertahan hidup dalam suatu lingkungan yang menyatu dengan sistem kepercayaan, norma, budaya dan diekspresikan dalam tradisi dan mitos yang dianut dalam jangka waktu yang lama. Fungsi kearifan lokal adalah Pertama, sebagai penanda identitas sebuah komunitas. Kedua, sebagai elemen perekat (aspek kohesif) lintas warga, lintas agama dan kepercayaan. Ketiga, kearifan lokal memberikan warna kebersamaan bagi sebuah komunitas. Keempat, mengubah pola pikir dan hubungan timbal balik individu dan kelompok dengan meletakkannya di atas kebudayaan yang dimiliki. Kelima, mendorong terbangunnya kebersamaan, apresiasi sekaligus sebagai sebuah mekanisme bersama untuk menepis berbagai kemungkinan yang meredusir, bahkan merusak, solidaritas komunal, yang dipercayai berasal dan tumbuh di atas kesadaran bersama, dari sebuah komunitas terintegrasi. Sedangkan menurut Rapanna (2016:4-6) kearifan lokal terdiri dari kamus Inggris Indonesia, terdiri dari 2 kata yaitu kearifan (wisdom) dan lokal (local). Local berarti setempat dan wisdom sama dengan kebijaksanaan. Dengan kata lain maka local wisdom dapat dipahami sebagai gagasangagasan, nilai-nilai, pandangan-pandangan setempat (local) yang bersifat bijaksana, penuh kearifan, bernilai baik, yang tertanam dan diikuti oleh anggota masyarakatnya. Kearifan lokal merupakan produk budaya masa lalu yang patut secara terus-menerus dijadikan pegangan hidup. Meskipun bernilai lokal tetapi nilai yang terkandung di dalamnya dianggap sangat universal. Kearifan lokal lahir dari pemikiran yang telah berkembang sejak lama, kearifan lokal lahir dari pemikiran dan nilai yang diyakini suatu masyarakat terhadap alam dan lingkungannya. Didalam kearifan lokal terkandung nilai-nilai, norma-norma, sistem kepercayaan, dan ide-ide masyarakat setempat.

Tanaman rempah empon-empon merupakan salah satu bentuk kearifan lokal di Dusun Madigondo. Hal yang menarik saat mengikuti Tracking adalah sesuatu yang dijumpai selama perjalanan. Sepanjang jalur Tracking Terbit Menoreh terdapat jenis-jenis tanaman rempah-rempah baik yang ditanam oleh warga ataupun yang tumbuh sendiri tanpa ditanam. Beberapa tanaman rempah yang bisa dijumpai antara lain jahe, kapulaga, temu lawak, kunyit, dsb. Pada masa pandemi Covid19 ini untuk memenuhi kebutuhan sehari-hari dan agar tanpa membeli, anggota komunitas Tracking Terbit Menoreh banyak yang menanam tanaman pangan dan dan tanaman bumbu rempah-rempah di sekitar rumahnya. Berdasarkan Hakim (2015: 25) manfaat kebun pekarangan rumah antara lain menyediakan 
pendapatan dan peningkatan aktifitas kerja, meningkatkan ketahanan pangan, dan meningkatkan kualitas lingkungan.

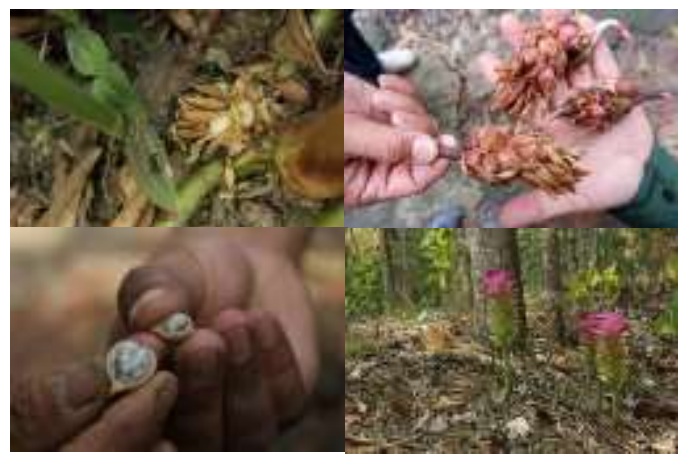

Sumber :Penulis (2020)

Gambar 3. Tanaman rempah-rempah di sekitar jalan Dusun Madigondo

Selama seperempat abad terakhir, baik penawaran maupun permintaan akan ekowisata telah tumbuh secara signifikan. Pada saat yang sama, ekowisata memiliki, sebagai bentuk tertentu perkembangan pariwisata, menjadi semakin diakui dan dilegitimasi sebagai sarana untuk mencapai pembangunan berkelanjutan di daerah tujuan. Saat ini wisatawan memiliki kecenderungan positif untuk mencari dan menikmati pengalaman pariwisata yang ramah lingkungan (Sharpley, 2006:7, 19). Dusun Madigondo mempunyai potensi terhadap pengembangannya menjadi kawasan ekowisata. Tracking Terbit Menoreh (TTM) ini merupakan inisiasi dari masyarakat dikelola oleh masyarakat setempat yaitu Komunitas Tracking Terbit Menoreh dengan didampingi oleh Koperasi Griya Jati Rasa dan Universitas Kristen Duta Wacana (melalui Pusat Studi Pembangunan dan Transformasi Masyarakat (PSPTM) \& Fakultas Arsitektur dan Desain (FAD)). Pembentukan dan proses perjalanan TTM ini dengan melibatkan partisipasi masyarakat setempat (participatory design) melalui pemetaan swadaya, FGD dan workshop. Berdasarkan Dukic and Volic (2017:10) upaya yang dimulai dengan langkah-langkah kecil harus dimulai, yang bisa dimulai dengan mengumpulkan komunitas lokal bersama-sama sehingga mereka dapat mulai merefleksikan kondisi lingkungan, materi, dan non-materi mereka. Mengidentifikasi apa yang dipunyai, yang tersedia dan apa yang terjadi bagi komunitas akan menjadi titik awal untuk pemetaan dan evaluasi sumber daya, karena dilihat dan dirasakan oleh penduduk setempat sendiri. Menurut Mastika (2018:251) pentingnya memahami pengembangan ekowisata didasarkan pada basis naluri kreatif, menghargai nilai-nilai kearifan lokal, mengerti, memahami serta menghayati arti dan makna menjaga keseimbangan hubungan manusia dengan manusia, alam, dan hubungaan dengan Sang Pencipta. Kemampuan intelektual dengan kekuatan lokal merupakan faktor utama bagi pengembangan ekowisata bertanggungjawab, bermanfaat, dan berkelanjutan. Ekowisata, Industri Kreatif, dan Kearifan Lokal merupakan "The Golden Triangle" modal dan kontribusi pariwisata bagi pembangunan pedesaan, konservasi, dan pembangunan berkelanjutan.Oleh karena itu, sudah seharusnya menjadi kesadaran, tekad, dan kebersamaan stakeholder bahu membahu memajukan ekowisata pedesaan yang berbasis industri kreatif berwawasan kearifan lokal.

Potensi Dusun Madigondo juga dikembangkan pada sektor industri kreatifnya. Azizah dan Muhfiatun (2017) menyatakan bahwa dengan harmonisasi ekonomi dan kearifan lokal dapat memicu daya saing ekonomi, meningkatkan produktifitas yang pada akhirnya meningkatkan taraf hidup masyarakat dengan tetap mempertahankan budaya, adat istiadat. Dusun Madigondo sangat tepat jika dikembangkan menjadi Community Based Eco-tourism (CBET). Sonjai dkk (2018: 262) menyatakan bahwa dalam mengoperasikan CBET, kekuatan kebijakan diadvokasi oleh pemangku kepentingan eksternal, dan partisipasi masyarakat menjadi faktor kunci dalam pengembangannya karena biasanya masyarakat lokal memiliki pengetahuan dan kompetensi terkait CBET yang terbatas. Pengembangan Dusun Madigondo ini juga tidak lepas dari peran serta stakeholder yang mendampingi dan berkolaborasi demi peningkatan di Dusun Madigondo. Ekowisata untuk wisatawan berpusat pada pengetahuan lokal, wisatawan belajar dari pengalaman untuk memahami dan menghargai kearifan lokal (Walter 2009:528). Pedoman pengetahuan masyarakat lokal dan budaya menjadi dasar untuk pengembangan ekowisata (Yi-fong, 2012:805). Ekowisata yang dikendalikan oleh komunitas atau masyarakat akan memiliki dampak positif pada komunitas tersebut termasuk sumber daya, penurunan migrasi, kontrol atas eksploitasi budaya dan lingkungan (Grieves, Adler, dan King., 2014: 83) 


\section{METODE PENELITIAN}

Metode yang digunakan dalam penelitian ini menggunakan metode penelitian atau peningkatan seseorang atau sekelompok orang melalui sebuah tindakan atau kegiatan dengan ruang lingkup terbatas dan di lokasi tertentu (Natawidjaja, 1995:2). Menurut Grundy dan Kemmis (1990:322), terdapat dua tujuan utama dalam penelitian tindakan, yakni untuk meningkatkan (to improve) dan untuk melibatkan (to involve). Analisis juga dilakukan secara spasial terhadap jalur Tracking wisata di Dusun Madigondo, terutama dalam hal tata lanskap yang menjadi daya tarik dari kegiatan Tracking. Kearifan lokal Dusun Madigondo berupa tanaman rempah empon-empon dimanfaatkan sebagai potensi utama untuk penataan salah satu spot atraksi utama yaitu di Kebun Curug Watu Jengger. Diharapkan melalui penelitian tindakan ini dapat mengembangkan aktivitas masyarakat pada masa pandemi Covid-19 yang berkaitan dengan tata lanskap jalur-jalur tracking dalam rangka mempertahankan eksistensi Dusun Madigondo sebagai destinasi wisata. Pemilihan tanaman berupa tanaman kopi, sayur mayur, tanaman obat di sepanjang jalur Tracking diharapkan dapat dimanfaatkan untuk penyediaan kebutuhan sehari-hari masyarakat pada masa Covid-19 ini dan untuk kedepannya memperkuat identitas Dusun Madigondo.

\section{HASIL DAN PEMBAHASAN \\ Tracking Terbit Menoreh di Masa Pandemi Covid-19}

Pada masa Covid-19 Dusun Madigondo mengalami dampak yang cukup signifikan. Aktivitas wisata di Dusun Madigondo menjadi terhenti karena menurunnya jumlah pengunjung yang datang, baik di Pawon Kopi Mbak Mar, Curug Watu Jengger, dan spot lainnya. Hal tersebut juga merupakan dampak dari penurunan pengunjung di Kabupaten Kulon Progo yang dapat dilihat di Gambar 2. Eksistensi Dusun Madigondo dimana sektor pariwisata menjadi andalan untuk peningkatan kegiatan ekonomi masyarakat menjadi terancam. Perlu strategi yang baik agar kondisi pariwisata di Dusun Madigondo ini tetap bertahan. Kegiatan Wisata Tracking Terbit Menoreh sudah mencapai pada tahap perencanaan dan siap untuk launching. Sebelum launching paket wisata Tracking TTM melakukan simulasi untuk mengetahui kendala dan permasalahan sebelum paket kegiatan dipublikasi dan dipromosikan kepada publik. Simulasi kegiatan dilakukan pada 19 Januari tindakan (action research), yakni penelitian dengan melakukan kajian dampak, respon

2020 dan diikuti oleh 8 orang peserta yang didampingi oleh 2 pemandu dari kelompok, dan seluruh anggota komunitas TTM beserta masyarakat sekitar. Setelah kegiatan simulasi direncanakan oleh komunitas beserta pendamping, Tracking Terbit Menoreh ini akan di-launching pada pertengahan Maret 2020. Namun, karena pada awal Maret di Indonesia sudah booming dengan pandemi Covid-19 sehingga rencana kegiatan yang dilakukan oleh komunitas mengalami penundaan dengan waktu yang belum ditentukan kembali.

Berdasarkan keterangan dari lbu Marwiyah dan Ibu Lastri selaku koordinator dan pengelola Tracking Terbit Menoreh, saat ini kegiatan wisata di Dusun Madigondo vakum sementara, masyarakat juga mengisi aktivitas kegiatan di rumah dengan menanam tanaman yang bisa dimanfaatkan untuk obat-obatan dan kebutuhan sehari-hari. Hal ini bisa dijadikan peluang dengan mengintegrasikan kegiatan tanam menanam yang dilakukan masyarakat di Dusun Madigondo menjadi salah satu support untuk menjaga eksistensi wisata Tracking dengan mengolah tata lanskap di jalur Tracking menjadi sebuah atraksi.

\section{Focus Group Discussion (FGD) Untuk Strategi Keberlanjutan Tracking Terbit Menoreh}

FGD dilakukan pada pada bulan Juni 2020 untuk kelanjutan proses kelanjutan rencana kegiatan Tracking Terbit Menoreh. Agenda utama dalam FGD ini adalah persiapan Tracking Terbit Menoreh dalam menyambut era kenormalan baru. FGD dilakukan di 2 tempat yaitu diawali dengan diskusi di Warung Kopi Mbak Mar yang merupakan spot 1 pada rute Tracking dan dilanjutkan melakukan survey dan diskusi lapangan di salah satu spot yaitu Kebon Curug Watu Jengger. Hasil dari FGD adalah:

1. Penerapan protokol kesehatan bagi pengelola dan pengunjung kegiatan tracking, di setiap spot tracking disiapkan peralatan protokol kesehatan, antara lain : thermo gun, masker, face shield, handsanitizer, dan sabun cuci.

2. Keberlanjutan jalur Tracking Terbit Menoreh pada masa kenormalan baru perlu diperhitungkan kembali terkait jarak tempuh dan waktu tempuhnya. Sehingga diputuskan untuk membuat alternatif rute Tracking, dengan rute tracking jarak pendek. 
3. Selama masa pandemi Covid-19 komunitas vakum melakukan kegiatan untuk tracking, dan lebih banyak beraktivitas di rumah dan sekitar rumah saja. Dalam rangka pemenuhan kebutuhan bahan pokok makanan sehari-hari berdasarkan diskusi, adalah jenis-jenis tanaman rempah-rempah karena pada masa pandemi Covid-19 ini minuman empon-empon yang yang dibuat dari rempah-rempah merupakan salah satu minuman untuk memperkuat imunitas tubuh sehingga daya tahan tubuh lebih baik dan tidak mudah terpapar Covid-19. Pengembangan kearifan lokal masyarakat Dusun Madigondo dengan pengetahuannya terkait olahan tanaman empon-empon (rempah-rempah) menjadi minuman/jamu dikembangkan untuk dinikmati warga sendiri dan sajian kuliner kegiatan tracking sekaligus alternatif kegiatan warga untuk meningkatkan pemasukannya. Menurut Rosas dkk (2018) pengetahuan ekologi tradisional yang diwujudkan dalam lanskap sebagai langkah untuk konservasi keanekaragaman hayati jangka panjang.

4. Spot Kebon Curug Watu Jengger menjadi spot yang utama untuk diolah lanskapnya menjadi kebun empon-empon dan bunga sebagai salah satu pengembangan kegiatan warga di masa pandemi, sekaligus menambah daya tarik dari tempat tersebut.

\section{Potensi Lahan Tanam di Kebon Curug Watu Jengger}

Curug Watu Jengger berada pada titik spot 6 pada rute perjalanan tracking. Tempat ini sempat booming pada awal tahun 2017 dikelola oleh masyarakat, namun karena kendala dana pengelolaan tempat ini sempat terbengkelai pada tahun 2018. Beberapa fasilitas masih dalam keadaan baik dan oleh komunitas Curug Watu Jengger akan dibangkitkan kembali salah satunya dengan dimasukkan menjadi spot titik pemberhentian rangkaian tracking. Karena Curug Watu Jengger dikembangkan menjadi salah satu spot yang dikembangkan tata lanskapnya terutama untuk tanaman rempah emponempon, berdasarkan kesepakatan bersama tempat ini kemudian diberi nama "Kebon Curug Watu Jengger". Pada musim kemarau air yang mengalir di curug sangat sedikit, bahkan cenderung kering, namun pada musim penghujan air yang mengalir pada curug ini sangat deras dan terasa segar. Pada sisi-sisi curug dan arah jalan masuk mempunyai potensi untuk dikembangkan lanskapnya karena saat ini hanya ditumbuhi oleh semaksemak yang tumbuh dengan sendirinya. warga memanfaatkan apa yang ada di sekitaran rumah dan kebun. Kegiatan di rumah tersebut diisi oleh warga di Madigondo dengan menanam tanamantanaman di sekitar rumah salah satunya

Potensi ini yang dimanfaatkan untuk pengembangan Kebon Curug Watu Jengger menjadi salah satu spot destinasi alam yang nantinya pengunjung dapat belajar tentang tanaman rempah-rempah yang dimanfaatkan menjadi sajian kuliner minuman herbal emponempon untuk kesehatan.

Pemetaan potensi dilakukan di Kebon Curug Watu Jengger. Beberapa spot akan ditanami dengan tanaman rempah dan juga bunga-bunga. Hal yang menjadi tantangan tersendiri adalah beberapa lahan mempunyai kontur yang sangat tajam, dan juga pada beberapa bagian merupakan tanah campur bebatuan.

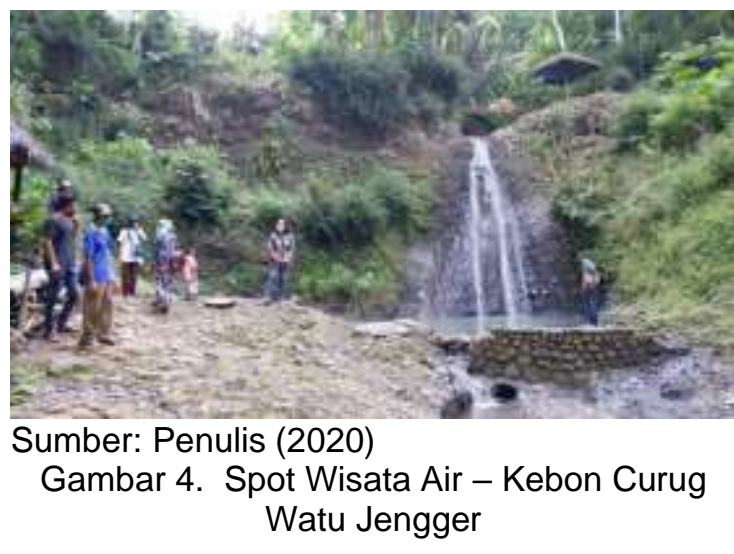

\section{Pemetaan dan Rencana Aksi Penataan Lanskap Kebon Curug Watu Jengger \\ Setelah melakukan identifikasi} permasalhan dan merumuskan strategi yang dilakukan pada saat FGD, kegiatan dilanjutkan dengan aksi penanaman tanaman rempah empon-empon sebagai bagian tata lanskap Kebon Curug Watu Jengger. Pemetaan dilakukan dengan metode workshop dimana komunitas sendiri yang merencanakan desain dari spot tersebut. Melalui metode participatory design ini diharapkan akan menumbuhkan rasa sense of belonging pada komunitas sehingga akan lebih terjaga keberlanjutan dari kegiatan Tracking Terbit Menoreh ini. Kegiatan yang diikuti oleh anggota komunitas yang berjumlah 15 orang dilakukan dengan tetap memperhatikan protokol kesehatan. Dengan disiapkan peta sketsa Kebon Watu Curug dan gambar-gambar sticker yang mewakili jenisjenis tanaman empon-empon, anggota komunitas berdiskusi untuk menentukan tata layout dari zonasi yang akan ditanam. Hasil 
dari pemetaan didapatkan bahwa di sekitar curug akan ditanami dengan tanaman bungabungaan, sisi utara degan tanaman kunyit, jahe dan jahe merah, sisi timur dengan tanaman kapulaga, kimpul / talas hijau, dan laos.

Kegiatan dilanjutkan dengan penanaman tanaman rempah empon-empon. sebenarnya merupakan kegiatan sehari-hari dan merupakan kearifan lokal yang dimiliki oleh masyarakat di Dusun Madigondo dapat menjadi support bagi keberlanjutan aktivitas Tracking Terbit Menoreh.

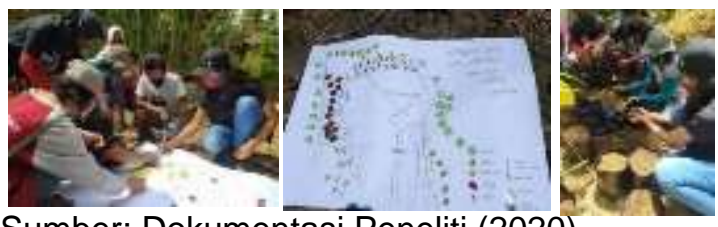

Sumber: Dokumentasi Peneliti (2020)

Gambar 5. Pemetaan dan Workshop Lanskap Rempah Empon-empon

\section{Branding Hasil Produksi Tanaman Rempah Empon-empon}

Anggota Komunitas TTM membuat beberapa hasil olahan tanaman rempahrempah tersebut menjadi bubuk instan yang siap diolah menjadi minuman dengan tinggal menambahkan atau diseduh dengan air. Jenis minuman herbal kesehatan/jamu instan yang sudah dibuat antara lain : jahe, kunyit, dan temu lawak. Kendala yang dialami oleh komunitas adalah masalah kemasan dan penyajian dari jamu instan tersebut, dan bagaimana pemasarannya. Hal tersebut dikarenakan keterbatasan kapasitas sumber daya manusia terhadap desain kemasan dan pemasaran secara online. Selain mengembangkan minuman dari tanaman rempah, komunitas juga mengembangkan sajian kuliner dari umbi-umbian. Gambar 5 (a) merupakan kemasan dan sajian yang sudah dibuat oleh komunitas yang akan dikembangkan packagingnya.

(a)

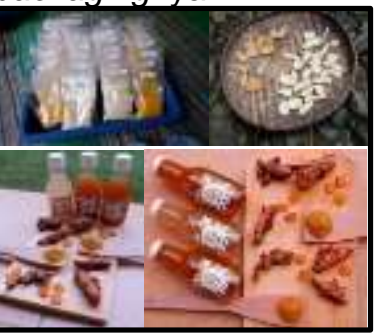

Sumber: Dokumentasi Peneliti (2020)

Gambar 6. (a) Hasil Pengolahan Umbi-umbian

(b) Pengembangan Packaging Empon-empon.

Proses pembuatan jamu empon-empon instan saat ini dilakukan dan dikembangkan oleh
Sebelum penanaman komunitas diberi materi pengantar dari narasumber yang sudah mempunyai pengalaman untuk budidaya tanaman rempah dan pengelolaannya. Komunitas mengikuti rangkaian kegiatan dengan sangat antusias, karena hal tersebut

kelompok dalam rangka mengisi kegiatan selama Covid-19. Sembari mempersiapkan sumber daya bahan dan materialnya, dikembangkan juga dalam hal packagingnya sehingga menjadi lebih menarik untuk dinikmat dan bagian dari rangkaian kegiatan Tracking Terbit Menoreh. Skenarionya adalah ketika wisatawan berkunjung akan disajikan minuman herbal empon-empon yang siap minum, dan wisatawan bisa membawa pulang kemasan instan atau kemasan yang siap minum. Gambar 5 (b) adalah gambar yang sudah dilakukan untuk mem-branding jamu empon-empon hasil karya komunitas Tracking Terbit Menoreh, yang dilengkapi dengan logo Tracking Terbit Menoreh dan nomor PIRT.

\section{PENUTUP}

Berdasarkan uraian tulisan di atas dapat disimpulkan bahwa masyarakat Dusun Madigondo tetap bersemangat dalam mengembangkan wisata Tracking Terbit Menoreh walaupun pada masa pandemi Covid-19. Hal tersebut dapat dilihat dari partisipasi masyarakat dan anggota komunitas dalam mempertahankan dan mengembangkan Dusun Madigondo menjadi sebuah destinasi wisata di Kabupaten Kulon Progo. Mereka terlibat aktif dalam setiap proses FGD dan workshop dalam mempertahankan eksistensi Dusun Madigondo. Kebersamaan dalam mengidentifikasi permasalahan dan merumuskan solusi bersama menjadi aspek yang sangat penting dalam mengelola kelembagaan komunitas Tracking Terbit Menoreh. Kearifan lokal masyarakat yaitu berupa tanaman rempah empon-empon menjadi salah satu identitas bagi pengembangan atraksi di rangkaian jalur tracking melalui pengolahan lanskap. Pengetahuan masyarakat untuk mengolah tanaman rempah menjadi minuman herbal empon-empon memberikan peluang aktivitas komunitas dan bagi peningkatan ekonomi masyarakat dan identitas bagi Dusun Madigondo.

Pada masa pandemi Covid-19, menjadi ujian bagi sebuah ketahanan sebuah komunitas masyarakat dalam mempertahankan eksistensinya. Penelitian ini 
masih sangat terbatas pada salah satu aspek yaitu kearifan lokal masyarakat, belum melihat pada aspek kapasitas masyarakat secara lebih mendetail. Perencanaan strategis pada sebuah komunitas atau masyarakat untuk meningkatkan kapasitasnya sangat diperlukan (Laverack, 2007: 179). Hal tersebut memberikan peluang untuk penelitian lanjutan dalam hal kapasitas dan ketahanan masyarakat, tidak hanya pada masa pandemi Covid-19 namun juga dalam menyambut era kenormalan baru.

\section{DAFTAR PUSTAKA}

Ahimsa-Putra, H S. 2009. Bahasa, Sastra, Dan Kearifan Lokal di Indonesia. Jurnal Mabasan. Vol. 3. No. 1. Pp. 30-57. https://doi.org/10.26499/mab.v3i1.115

Azizah, S N dan Muhfiatun. 2017. Pengembangan Ekonomi Kreatif Berbasis Kearifan Lokal Pandanus Handicraft dalam Menghadapi Pasar Modern Perspektif Ekonomi Syariah (Study Case di Pandanus Nusa Sambisari Yogyakarta). Aplikasia : Jurnal Aplikasi IImu-ilmu Agama. Vol. 17. No. 2. Pp. 6378.

Dukic, V and Volic, I. 2017. The Importance of Documenting and Including Traditional Wisdom in Community-Based Ecotourism Planning : A Case Study of the Nature Park Ponjavica in the Village of Omoljica (Serbia). SAGE Open : Special Issue Traditional Wisdom. January-March 2017. Pp. 1-11.

DOI:10.1177/2158244016681048.

Grundy, S. and Kemmis, S. 1990. Educational Research in Australia: The State of the Art (an Overview). Dalam S. Kemmis \& R. McTaggart (Eds.). The Action Research Reader. Victoria: Deakin University

Grieves, M., Adler, M., and King, R. (2014). To Preserve the Mountains and the Community : indigenous Ecotourism as a Sustainable Development Strategy. Social Thought \& Research. Vol 33. Pp. 83-111

Hakim, L. 2015. Rempah dan Herba KebunPekarangan Rumah Masyarakat: Keragaman, Sumber Fitofarmaka dan Wisata Kesehatan-kebugaran. Yogyakarta: Diandra Creative.
Laverack, G \& Thangpet, S. (2007). Building Community Capacity for Locally Managed Ecotourism in Northern Thailand. Community Development Journal. Vol.44 No.2. $\quad \mathrm{Pp}$ 172-185. DOI:10.1093/cdj/bsm058

Mastika, I.K. (2018). Pengembangan Ekowisatan Berwawasan Kearifan Lokal Di Wilayah Eks Karesidenan Besuki, Jawa Timur. Jurnal JUMPA. Vol. 4. No. 2. Pp. 240-252.

Natawidjaja, R. 1995. Pokok-Pokok Pikiran mengenai Penelitian Kelas. Jakarta : UP3SD Dirjen DIKTI Depdikbud

Prabandari, D., Avenzora, R., dan Sunarminti, T. 2018. Kearifan Lokal Untuk Pengembangan Ekowisata di Bogor. Media Konservasi. Vol. 23. No. 3. Pp. 274-280.

Rapanna, P. (2016). Membumikan Kearifan Lokal Dalam Kemandirian Ekonomi. Makassar: CV Sah Media.

Sonjai, N.P., Bushell, R., Hawkins, M., Staiff, R. 2018. Community-based Ecotourism: Beyond Authenticity and The Commodification of Local People. Journal of Ecotourism. Vol. 13. No. 3. Pp. 252267.

https://doi.org/10.1080/14724049.2018.15 03502.

Sharpley, R. 2006. Ecotourism : A Consumption Perspective. Journal of Ecotourism. Vol. 5. No, 1\&2. Pp. 7-22. DOI: $10.1080 / 14724040608668444$

Walter, P. 2009. Local Knowledge and Adult Learning in Environmental Adult Education: Community-Based Ecotourism in Southern Thailand. International Journal of Lifelong Education. Vol. 28. No. 4. Pp. 513-532. DOI: 10.1080/02601370903031363

Yi-fong, C. 2012. The Indigenous Ecotourism and Social Development in Taroko National Park Area and San Chan Tribe, Taiwan. GeoJournal (2012) 77. Pp. 805815.

Rosas, N.V. et. al. (2018). Traditional Ecological Knowledge as a tool for Biocultural Landscape Restoration in Northern Veracruz, Mexico : A Case Study in El Tajin Region. Ecology and Society. Vol $23 . \quad$ No. 3. https://doi.org/10.5751/ES-10294230306. 